\title{
TECHNOLOGIES FOR GREEN REVOLUTION ARE PRECARIOUS IN PUBLIC EDUCATION INSTITUTION
}

\author{
Aurélio Ferreira Borges ${ }^{1}$ \\ Maria dos Anjos Cunha Silva Borges ${ }^{2}$ \\ José Luiz Pereira de Rezende ${ }^{3}$ \\ Thais Muniz Otoni Santiago ${ }^{4}$ \\ Suely Cunha da Silva ${ }^{5}$
}

\begin{abstract}
The objective of the study is to characterize the greening of undergraduate courses in public education institution. The information was obtained through the evaluation of the curriculum and teaching plans of disciplines. The educational plan of the courses showed the parameters: commitment to the transformation of society and nature relations; narrowing of issues around the relationship between society and nature and the inclusion of disciplines that have concern for environmental issues.
\end{abstract}

Keywords: Rural Extension; Curricular Environmentalization; Society and Nature.

RESUMO: O objetivo do estudo é caracterizar a ambientalização curricular de cursos de graduação de instituição de ensino pública. As informações foram obtidas por meio da avaliação da grade curricular e dos planos de ensino das disciplinas. O plano pedagógico dos cursos apresentou os parâmetros: compromisso para a transformação das relações sociedade e natureza; estreitamento das questões ligadas à relação entre sociedade e natureza e a inserção de disciplinas que apresentam preocupação com questões ambientais.

Palavras-chave: Extensão Rural; Ambientalização do Currículo; Sociedade e Natureza.

\section{Introduction}

\footnotetext{
${ }^{1}$ Universidade Federal de Lavras. E-mail: aferreiraborges@gmail.com

${ }^{2}$ Senai, Rondônia. E-mail: maria.cunhaborges@gmail.com

${ }^{3}$ Universidade Federal de Lavras. E-mail: jlprezen@ufla.br

${ }^{4}$ Universidade Federal de Lavras. E-mail: thaismottoni@gmail.com

${ }^{5}$ O Boticário Franchising. E-mail: borgesmaria20012001@yahoo.com.br
}

Revbea, São Paulo, V. 10, Nº 1: 12-19, 2015. 
Tbilisi Conference (1977) achieved in the domain of International Environmental Education Programme (PIEA), coordinated by the United Nations for Education, Scientific and Cultural Organization (UNESCO) and United Nations Environment Programme (UNEP), has summoned Member States to include curricular adjustment in their policies of environmental suitability. These steps aim to incorporate the environmental dimension into their systems, based on principles defined by it. Among these principles, the conference recommended that the Environmental Education (EE) should understand the entire context of the levels of school education and adopt a global focus and marked out a wide interdisciplinary basis, from which one takes the interdependence of ecological, social economic and cultural factors.

With support in the Chicago Statement, prepared at the International Conference of Holistic Educators, it appeared in 1997 the term Holistic Education (PERINI-SANTOS, 2004). According to this Declaration, the educational processes of the twenty-first century should be supported in the fundamentals of holism. It emphasizes the challenge of promoting a sustainable, equitable and peaceful society in harmony with the earth and its life. The holistic view seeks to enhance the way we visualize and the interdependence we have with the world, magnifying our innate human potential: the intuitive, emotional, physical, imaginative and creative as well as rational, logical and verbal.

According to Marchesan et al. (2010), the information generated by Brazilian research activities takes place through official research institutions that establish their individual priorities. There are few areas that carry out research cooperatively among institutes, universities and private companies. The universities have their research priorities linked to graduate programs that involve more academic pursuits. On the other hand, rapid investment return is a high priority to private companies. As a result, there is a lack of cooperative work which often results in loss of market opportunities. The lack of communication between researchers of institutions and various users of technology limited the usefulness of research done to initially develop the technology. The interactions between the various users allow for anticipation of future potential needs, identifying new agribusiness opportunities.

View this author, technology validation is fundamental, not only to producers and technicians, but also to researchers. In some cases, technology adaptations are necessary due differences in climate conditions, soil characteristics, field management methods, farm culture. This is important to feedback into the research system.

According to him, there are several systems of technology transfer for rural areas. One is the Training \& Visiting (T\&V) was used in many developing countries from 1975 to 1998, especially in Africa and Asia with the objective of helping increase the adoption of Green Revolution technologies. It was a rigorous training program demanding discipline and leadership. According to Anderson et al. (2006, cited by MARCHESAN et al., 2010), the system was 
called "top down" technologies, without interaction with the community where it was implemented.

In this respect, the research problem arises of the question: what are the characteristics of the greening ecology in the undergraduate courses in public education institution?.

\section{Material and Methods}

It was verified the level of adjustment in the formation of undergraduates to know about the introduction level on thematic areas of environmental nature. This information was obtained by analyzing the curriculum and teaching plans of undergraduate disciplines to diagnose the theme environment. The analysis of the subjects occurred at two levels of complexity. Condition 1: analysis of teaching plans (menus, objectives, contents and references) from the disciplines of the undergraduate courses. Condition 2: analysis of the curriculum (menus, objectives, contents and references) of undergraduate courses.

The investigation about the adjustment of education in Rio Verde Campus, was conducted with ten undergraduate courses. It was taken as reference two sources of information of institutional nature, namely the Curriculum Matrix (M) and Plans for Teaching Subjects (P).

From the explicit comprehension of the 10 characteristics (Table 1), adapted from Freitas et al. (2003), taking as references the scales M (curriculum of undergraduate courses) and $P$ (teaching plans of undergraduate courses) sought to identify the presence of indicators for the 10 characteristics to 10 undergraduate courses that the Rio Verde Campus offers to the community. For the scale $\mathrm{M}$, which analyzed the number one characteristic of an environmentalized course, it was analyzed the curriculum menus, objectives, contents and references; to the scale $P$, which analyzed the other 09 features which verified the characteristics of an environmentalized course, it was analyzed the menus, objectives, contents and references of the disciplines that constitute the undergraduate courses.

Data analysis was performed using a statistical package for Windows SPSS (Statistical Package for Social Science) software version 11.5 (2002) and Microsoft Office Excel 2007 software. 
Table 1: Ten characteristics of an environmentalized course.

\begin{tabular}{ll}
\hline CHARACTERISTICS & \multicolumn{1}{c}{ UNDERSTANDING OF ITS MEANING } \\
\hline $\begin{array}{l}\text { 1. Commitment to } \\
\text { transform society- } \\
\text { nature relations. }\end{array}$ & $\begin{array}{l}\text { Reconstruction of attitudes, individual and collective } \\
\text { practices that generate actions to transform the } \\
\text { socio-cultural and natural environment. }\end{array}$ \\
\hline $\begin{array}{l}\text { 2. Complexity } \\
\text { (worldview). }\end{array}$ & $\begin{array}{l}\text { Presence of complex thought and of the } \\
\text { interdisciplinar paradigm in the way of looking, feeling } \\
\text { and being in the world. }\end{array}$ \\
\hline $\begin{array}{l}\text { 3. Disciplinary order: } \\
\text { flexibility / } \\
\text { permeability. }\end{array}$ & $\begin{array}{l}\text { Facilitate dialogue with the differences of } \\
\text { philosophical, metaphysical and epistemological } \\
\text { positions in a permanent analysis of the training } \\
\text { processes. }\end{array}$ \\
\hline $\begin{array}{l}\text { 4. Contextualize the } \\
\text { local-global-local. }\end{array}$ & Integrate the knowledge / concepts to daily social life. \\
\hline $\begin{array}{l}\text { 5. Consider the } \\
\text { subject in building } \\
\text { knowledge. }\end{array}$ & $\begin{array}{l}\text { Build diverse environment for the manifestation of } \\
\text { personality differences, which ensures the } \\
\text { participation of students in the intellectual and } \\
\text { emotional field. }\end{array}$ \\
\hline $\begin{array}{l}\text { 6. Consider cognitive / } \\
\text { affective aspects of } \\
\text { those involved. }\end{array}$ & $\begin{array}{l}\text { Provide material, structural, pedagogical, } \\
\text { psychological support to form skills, construct } \\
\text { knowledge and produce forms of expression (art, } \\
\text { philosophy, religion, politics). }\end{array}$ \\
\hline $\begin{array}{l}\text { 7. Consistency and } \\
\text { reconstruction of } \\
\text { theory and practice. }\end{array}$ & $\begin{array}{l}\text { Exercise of reflection in knowledge production that } \\
\text { combines theoretical and practical movements. }\end{array}$ \\
\hline $\begin{array}{l}\text { 8. Forward-looking of } \\
\text { alternative scenes. }\end{array}$ & $\begin{array}{l}\text { Commitment with building visions of science, society, } \\
\text { technology and environment in a responsible } \\
\text { perspective with the current and future generations. }\end{array}$ \\
\hline $\begin{array}{l}\text { 9. Methodological } \\
\text { adequacy. }\end{array}$ & $\begin{array}{l}\text { Link between educational practices and theories that } \\
\text { justify them, from evaluative models that support the } \\
\text { link. }\end{array}$ \\
\hline $\begin{array}{l}\text { 10. Space for } \\
\text { reflection and } \\
\text { democratic } \\
\text { participation. }\end{array}$ & $\begin{array}{l}\text { Creation of strategies for democratic } \\
\text { participation, with autonomy to make } \\
\text { decisions and implement them (political, } \\
\text { administrative, material, economic support). }\end{array}$ \\
\hline
\end{tabular}

Source: adapted from Freitas et al. (2003).

\section{Results and Discussion}

From the curriculum it was found that Environmental Management course showed greater integration into a curriculum characteristic 1: commitment to the transformation of society-nature relations. This is probably is related to the nature of knowledge since the object of study in this area has an extremely close connection with issues related to the relationship between society and nature. In view of this specificity, the number of subjects who had an explicit concern with this characteristic was significant, i.e., the 54 subjects that were analyzed 36 of them study the relationship between society and nature.

A fact which may help interpret this significant result of Environmental Management course was the marked presence in offering disciplines about

Revbea, São Paulo, V. 10, N 1: 12-19, 2015. 
environmental chemistry, environmental biology, environmental management, agroecology and solid waste.

On the other hand, when looking at areas of Bachelor, Licenciature, Engineering and Technology, it was found that the number of environmentalized subjects in the curriculum per area was very low.

Among the 201 disciplines from courses of Animal Science, Chemistry and Biology, Bachelor Degree areas, only 17 were found, i.e., 8.4\% had features that characterize the concern with the characteristic 1 (commitment to the transformation of relations between society and nature).

Among the 133 disciplines from courses of Agronomy and Food Science, Engineering area, only 11 have characterized this concern with the characteristic 1 , or $8.3 \%$.

Among the 120 subjects analyzed in Chemistry and Biology courses, Licenciature area in Rio Verde Campus, had eight points that characterize the concern with the characteristic 1 , i.e. only $6.7 \%$.

Among the 79 disciplines from courses of Agribusiness and Grain Production in the area of Technology, 15 subjects, i.e. $19 \%$ of the subjects marked the characteristic 1.

Among the 54 subjects of the Environmental Technology course, 36 subjects, or $66 \%$ of the subjects marked the characteristic 1 .

A fact that could help interpret this result slightly lower in Licenciature area compared to other areas is the marked absence in offering disciplines about environmental chemistry, environmental biology, environmental management, agroecology and solid waste in teaching plans of Licentiateship in Chemistry and Biology.

For the classification of necessary information on teaching plans in the other nine characteristics, it was analyzed the disciplines of the undergraduate courses.

Among the 79 disciplines from courses of Agribusiness and Grain Production, Technology area, the average was 8.5 characteristics for the other nine characteristics of an environmentalized undergraduate course, whose average was equivalent to $7.9 \%$ of 77 characteristics (Table 2).

Among the 133 disciplines from courses of Agronomy and Food Science, Engineering area, the average was 7.5 characteristics for the other nine characteristics of an undergraduate course environmentalized, whose average was equivalent to $11 \%$ of the 68 characteristics (Table 2).

Then from 201 subjects of Animal Science, Chemistry and Biology, Bachelor Degree courses, the average was 6.1 characteristics for the other nine characteristics of an undergraduate course environmentalized, whose average amounted to $11.1 \%$ of the total 55 characteristics (Table 2). 
Table 2: Teaching plans of 10 undergraduate courses concerned with 9 characteristics for an environmentalized course in 2009.

\begin{tabular}{llllll}
\hline Área & Technology & Engineering & $\begin{array}{l}\text { Bachelor } \\
\text { degree }\end{array}$ & Licenciature & EM \\
\hline $\begin{array}{l}\text {-Total of } \\
\text { characteristics }\end{array}$ & 77 & 68 & 55 & 40 & 175 \\
$\begin{array}{l}-\quad \text { Average of } \\
\text { characteristics }\end{array}$ & 8.5 & 7.5 & 6.1 & 4.4 & 19.4 \\
$\begin{array}{l}-\% \text { average of } 9 \\
\text { characteristics }\end{array}$ & $7.9 \%$ & $11.0 \%$ & $11.1 \%$ & $11.0 \%$ & $11.1 \%$ \\
\hline
\end{tabular}

Source: survey data using the Microsoft Office Excel 2007 software and SPSS (Statistical Package for Social Science) software, version 11.5 (2002).

From 120 subjects analyzed in Chemistry and Biology, courses of Technology, the average was 4.4 for the other nine characteristics of an undergraduate course environmentalized, whose average was equivalent to $11 \%$ of 40 characteristics (Table 2).

Among the 54 subjects from the of Environmental Management course (GA), the average was 19.4 characteristics for the other nine characteristics of an undergraduate course environmentalized, whose average amounted to $11.1 \%$ of the total of 175 characteristics (Table 2).

Analyzing the percent average of these 9 characteristics, it was found that the lowest value was Technology area, with a value of $7.9 \%$. For the other four areas these percentages were equivalent to $11 \%$ (Table 2).

For all areas analyzed, did not occur the offering of elective subjects. Elective subjects were offered only for the Agronomy course from the second half of 2010 . The compulsory subjects corresponded to approximately $100 \%$ of the curriculum of all other undergraduate courses.

In a study conducted in teaching plans of undergraduate courses at the University of Santiago de Compostela in Spain, Garcia (2001) found that teaching plans of the degree in Biology, Technical Engineering in forestry and degrees in Pharmacy and Chemistry were those who had the highest levels of environmentalization, with values that reached $27.4 \%, 18.2 \%, 11.9 \%$ and $10.7 \%$ of subjects, respectively. On the other hand, the curriculum of the Degrees in Law and Political Science did not have environmentalized disciplines, while a degree in Economics had $0.83 \%$ of subjects environmentalized. Averaging environmentalized disciplines of all undergraduate courses, this author found that the average total was equal to $10.2 \%$.

In a research carried out in a Brazilian public university, Zuin et al. (2009) found that the total number of subjects $(n=43)$ which composed the curriculum 
of the undergraduate course in Chemistry, 30\% were directed to curricular environmentalization.

\section{Conclusions}

Evidence of the paradigm of complexity was identified from the reference made in the programs, when trying to relate the expertise of a given discipline to the others.

The characteristics of an environmentalized course in teaching plans and curriculum were significant in the course of Technology in Environmental Management. The presence of the Technology courses suggested that this factor is determinant in the process of curricular environmentalization.

The campus did not develop a policy that allows connection to empower the process environmentalization of the different undergraduate courses. There is definition of a set of elective subjects only in the course of Agronomy, occurring only from the second half of 2010.

It is essential to reconstruct the practices of teaching and learning that occur in public education institution and in rural extensions. Given the premise that the processes of teaching and learning need to aim to methodology that results in a more sustainable society and more collective and humanitarian, becomes necessary a practice centered on dialogic communication together with farmers, in order to organize a new reality for the rural environment.

\section{References}

ANDERSON, J.R. et al. The rise and fall of training and visit extension: an Asian mini-drama with an African epilogue. World Bank Policy Research Working Paper n. 3928, 2006. Available from: $<$ http://econ.worldbank.org/external/default/ main?pagePK=64165259 \&piPK=64165421\&theSitePK $=469372 \& \mathrm{~m}$ e n u P K =6 4216926 \&entitylD=000016406 20060519144915>. Access on: december 10, 2011.

FREITAS, D. et al. Diagnóstico do grau de ambientalização curricular no ensino, pesquisa, extensão e gestão na Universidade Federal de São Carlos. In: GELI, A.M. et al. (Org.). Ambientalización curricular de los estudios superiores. Girona: Universitat de Girona, 2003. p. 167-204.

GARCÍA, M.C. La ambientalización de la universidad. 2001. 610 f. Tese (Doutorado em Educação) - Universidade de Santiago de Compostela, Santiago de Compostela, 2001. Availablefrom:<http://www.cervantesvirtual.com/buscador/?q=la+ambientalizaci \%C3\%B3n+de+la+universidad\&f[cg]=1>. Access on: December 10, 2011. 
MARCHESAN, E. et al. Brazilian university technology transfer to rural areas. Ciência Rural, v.40, n.10, Oct. 2010. Available from: $<$ http://www.scielo.br/scielo.php?script=sci arttext\&pid=S010384782010001000 031\&lng=en\&nrm=iso>. Access on: December 10, 2011. Epub Oct 29, 2010. http://dx.doi.org/10.1590/S0103-84782010005000177.

MICROSOFT. Programa excel 2007. Disponível em: $<$ http://office.microsoft.com/en-us/excel-help/up-to-speed-with-excel-2007 RZ010062103.aspx>. Access on: april 11, 2011.

PERINI-SANTOS, E. Conteúdo não conceitual, holismo e normatividade. Kriterion, Belo Horizonte, v. 45, n. 110, december 2004. Available from: $<$ http://www.scielo.br/scielo.php?script=sci arttext\&pid=S0100-

512X2004000200004\&lng=pt\&nrm=iso>. Access on: December 11, 2011. http://dx.doi.org/10.1590/S0100-512X2004000200004.

SPSS. Spss 11.5: statistical algorithms. SPSS, Inc: Chicago, IL, 2002.

ZUIN, V.G.; FARIAS, C.R.; FREITAS, D.A ambientalização curricular na formação inicial de professores de química: considerações sobre uma experiência brasileira. Revista Electrónica de Enseñanza de las Ciencias, Vigo, v. $8, \quad$ n. 2 , p. 1-19, 2009. Available from:<http://reec.uvigo.es/volumenes/volumen8/ART10 Vol8 N2.pdf.>. Access on: December 10, 2009. 